UDC 66.095:678.744

\author{
T.P. Kovalenko, V.O. Serdiuk, V.B. Vostres, H.F. Matiko
}

\title{
EMULSION COPOLYMERS OF METHYL ACRYLATE AND DECYL (METH)ACRYLATE: SYNTHESIS AND PROPERTIES
}

\author{
Lviv Polytechnic National University, Lviv, Ukraine
}

\begin{abstract}
This paper reports a kinetic investigation into the emulsion (co)polymerization of decyl meth- and decyl acrylate with methyl acrylate for the first time. The obtained results are used to prepare copolymers based on the products of the emulsion (co)polymerization. It is determined that decyl methacrylate does not homopolymerize with the formation of emulsions regardless of the nature of an emulsifier, its solubility and initiator structure. Moreover, they reduce the rate of copolymerization with methyl acrylate. The deceleration of the copolymerization in the presence of long-chain monomers is related to the a low activity of decyl (meth)acrylate as compared with methyl acrylate. The colloid-chemical and physicochemical properties of the synthesized dispersions are investigated. The position of the maximum of the dependences of viscosity and surface tension on the polymer composition coincides with the smallest particle sizes of the dispersion; hence, the alterations in the viscosity and surface tension of the dispersion are associated with the variations in particle sizes, which results in the changes in the interface surface area. The molecular weight distribution of emulsion copolymers is studied by a turbidimetric titration technique. The absorption of water, the strength and specific elongation of the (co)polymer films are determined by tension testing. Diffusion coefficients are calculated according to the first section of the water absorption curve; the obtained values show the deceleration of the rate of the water absorption by the copolymer film as compared with the polymethylacrylate films. The tensile strength of the poly(methyl acrylate-co-decyl acrylate) films is less than that of the poly(methyl acrylate-co-decyl methacrylate) ones, which corresponds with the well-known facts concerning the influence of a methyl substituent in an $\alpha$-position on the polymer properties. The addition of hydrophobic co-monomers, decyl meth- and decyl acrylate, to the structure of macromolecules with methyl acrylate strongly affects the properties of the dispersion and derived films, which is connected with the significant structural transformations of macromolecules in the dispersions and films.
\end{abstract}

Keywords: kinetic investigation, emulsion (co)polymerization, decyl (meth)acrylate, methyl acrylate, colloid-chemical and physicochemical properties.

DOI: $10.32434 / 0321-4095-2019-127-6-99-106$

\section{Introduction}

Comb polymers (CPs) belong to a particular type of polymers in which macromolecules contain long side branching situated relatively frequent along the main chain. CPs refer to the homologous series of higher poly( $\alpha$-alkene)s, poly(1-alkylethylene)s, poly(acrylate)s and poly(alkyl methacrylate)s with rather long aliphatic fragments in the side chain, poly(vinyl alkyl ester)s, complex polyesters, poly(acyl styrene)s, poly(acrylic acid) derivatives of amino acids, comb-shaped polypeptides, etc. [1-3].

Branching of hydrocarbon chains usually varies within 5 to 20 repeating units occurring between branch points, but the side chains in such polymers may be very different and include carbocyclic, heterocyclic, amide, alkyl-aromatic and other fragments, however, the hydrocarbons are the most frequent ones. It is important that the lengths of these side chains significantly exceed their crosssection [3]. Only under these conditions, specific complex of CPs can appear.

A special feature of these polymers is the presence of two types of fragments participating in the main chain formation, whereas branching occurs

(C) T.P. Kovalenko, V.O. Serdiuk, V.B. Vostres, H.F. Matiko, 2019

Emulsion copolymers of methyl acrylate and decyl (meth)acrylate: synthesis and properties 
with another of those fragments. These side branches and the main chain are directly linked by carboncarbon, ester, amide, etc. bonds. The existence of the main chain, in which the side fragments are pendant, flexible and inclined towards the intermolecular interactions with other macromolecular main chains, allows discovering such qualities of these polymers that are due to the specific constitution of the main chain.

One of the methods of the preparation of CPs is a copolymerization of long-chain (meth)acrylates affected by the different functionality of a monomer. This permits influencing both the nature of intrinsic and intermolecular interactions of CPs and the properties of the finished products.

The preparation of CPs mainly relates to the synthesis of poly(methyl acrylate) improvers for petrochemical products [4-6]. These polymers are characterized by a relatively low molecular weight, low content of monomer modifiers and ability to conformational alterations within petrochemical products within the temperature range of -40 to $+100^{\circ} \mathrm{C}$.

Unsaturated acids are frequently used as emulsion polymer modifiers, thus allow them to affect the hydrophilic-hydrophobic balance of macromolecules [7]. The modification of emulsion polymers by unsaturated long-chain alcohol esters, able to influence the hydrophilic-hydrophobic balance, has not been investigated yet.

We used decyl (meth)acrylates to study a macromolecule hydrophobization, change their polymer particle packing and influence the state and size of hydrated shells formed by water molecules around polymer particles.

\section{Material and methods}

Methyl acrylate (MA) (Merck) was used which was previously separated from an inhibitor by distillation; the yield was not less than $99.0 \%$. Decyl acrylate (DA) and decyl methacrylate (DMA) were synthesized by esterification from 1-decanol and acrylic or methacrylic acid, respectively [8]. Ammonium persulphate (APS) (Aldrich) was not less than $98.0 \%$ pure. Sulphonic neonol AF 9-10 (SAF 9-10) was produced by Barva (Ukraine). Benzene (Aldrich) and acetone (Aldrich) were not less than $99.0 \%$ pure.

The poly(MA-co-DA)s and poly(MA-coDMA)s based on the MA, DA or DMA, in their various ratios, were synthesized by emulsion (co)polymerization. The general structure of the prepared poly(MA-co-D(M)A) is shown as follows Schema.

The kinetic measurements of the emulsion

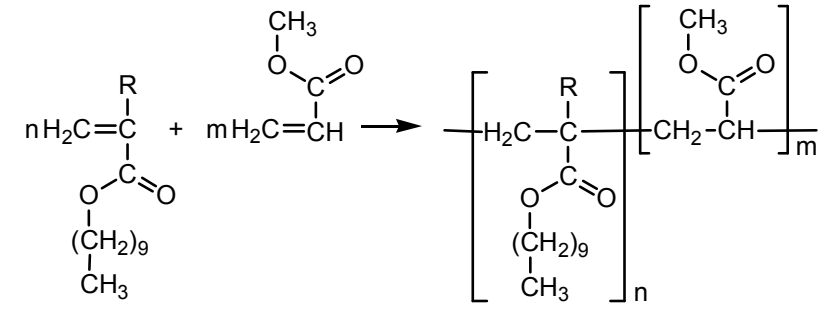

where $\mathrm{R}-\mathrm{H}, \mathrm{CH}_{3}$

Schema

(co)polymerization of MA with $\mathrm{D}(\mathrm{M}) \mathrm{A}$ were accomplished by a gravimetric method at $70^{\circ} \mathrm{C}$ under argon atmosphere in a glass round-bottom flask equipped with a reflux condenser, stirrer, thermometer, dropping funnel and inlet to inflate the flask with argon. SAF 9-10 was used as an emulsifier (4.0 wt.\% of the MA weight), while the monomers and aqueous phase were in proportion of 1:4. APS was used an initiator. The initiator concentration was adjusted in such a way as to obtain the kinetic curve of the MA emulsion polymerization approximately close to $100 \%$ conversion. The specimens of the colloidal solution were sampled and transferred into glass weighing bottles; the water and monomers were removed at $30-40^{\circ} \mathrm{C}$ in vacuo. The formed film was additionally kept at $60^{\circ} \mathrm{C}$ for 10-12 hours. The conversion was calculated by the residuum weight.

The dispersions of poly(MA-co-D(M)A) with the $\mathrm{D}(\mathrm{M}) \mathrm{A}$ content in the monomer mixture up to 25 wt.\% were prepared by the addition of the monomers to the fore-emulsion aqueous phase at $70 \pm 1^{\circ} \mathrm{C}$ for $1.0-1.5$ hours and further held at this temperature for 2 hours. APS was used as an initiator (0.3 wt.\% of the MA weight). SAF 9-10 was an emulsifier ( 6 wt. $\%$ of the MA weight). The dispersion yield was equal to $98-99 \%$, which ensured a correspondence between the integral copolymer and monomer mixture content.

The particle sizes of the dispersion were measured by the absorbance versus incident light wavelength dependence using a KF-77 photocolorimeter. The surface tension of the polymer dispersion with different $\mathrm{D}(\mathrm{M}) \mathrm{A}$ content was determined by the du Nouy method. The viscosity of the dispersion was measured by means of a VPG-2 capillary viscometer (the instrument constant was equal to $1.09 \cdot 10^{-2}$ ). A turbidimetric titration was performed using a KFK-2MP photocolorimeter at a wavelength of $340 \mathrm{~nm}$. Acetone was a solvent for the synthesized emulsion copolymers and water was a precipitant as well. 


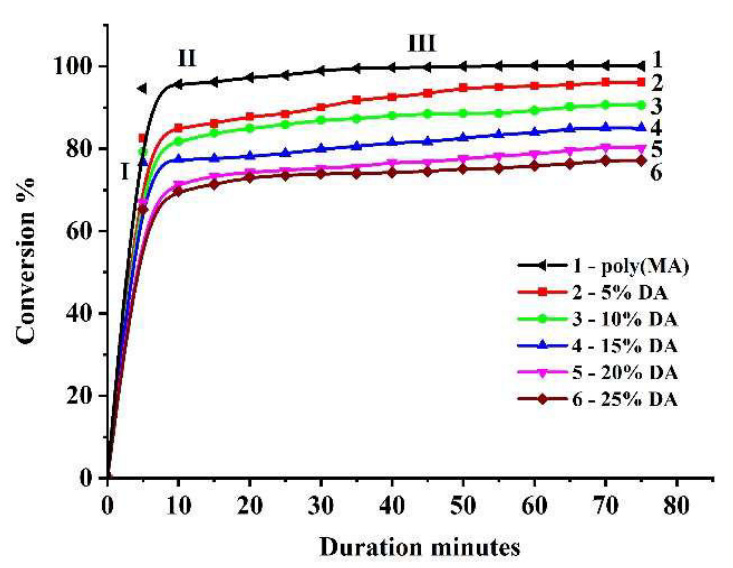

a

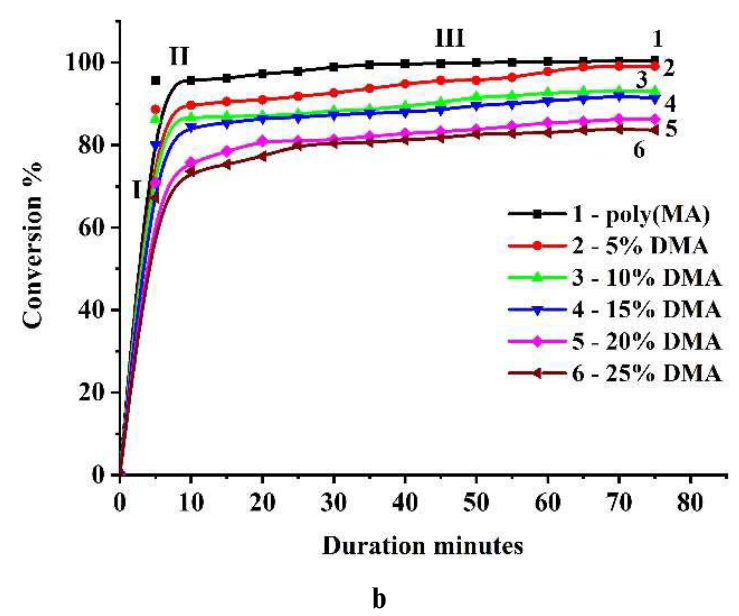

b

Fig. 1. Kinetic curves of the (co)polymerization for the different $\mathrm{D}(\mathrm{M}) \mathrm{A}$ concentrations in the monomer mixture (wt.\%): (a) poly(MA-co-DA) and (b) poly(MA-co-DMA)

The rectangular strips $(10 \times 80 \mathrm{~mm})$ with a thickness of $0.20-0.25 \mathrm{~mm}$ were used for the physical-mechanical investigations of the dispersion films. The obtained film samples were tested by a TIRA test 2200 tensile machine. Every sample was tested in triplicate.

IR spectra of (co)polymers were recorded using a Specord IR-80M spectrometer within the region of 4000 to $400 \mathrm{~cm}^{-1}$ (a film, KBr).

\section{Results and discussion}

The kinetic curves of the MA homopolymerization demonstrate three following typical sections: a stationary flow of the process at a constant rate (I), an abrupt slowdown of the reaction rate (II) and an almost full completion of the reaction (III) (Fig. 1).

The process of the copolymerization of the monomer modified with MA involves similar first two sections; however, the reaction does not end in the third section and proceeds slowly until a constant value of conversion. DA influences significantly upon the kinetics of the emulsion copolymerization when compared to DMA [9]. The deceleration of the copolymerization in the presence of the long-chain monomers is observed. This may be associated both with a low activity of $\mathrm{D}(\mathrm{M}) \mathrm{A}$ during the copolymerization as compared with MA and with a decrease in the share of the reaction that occurs according to the homogeneous nucleating mechanism resulted from a MA redistribution in the polymermonomer particle (PMP) in the presence of the monomer modifiers. The D(M)A emulsion homopolymerization does not occur under similar conditions which is connected with both a low activity of the monomer modifiers during the polymerization and absence of oligomer radicals formed in the aqueous phase; this causes the penetration of initiating particles into the PMP.

Based on the results of kinetic investigations for the emulsion copolymerization of the long-chain (meth)acrylates and well-known quantitative correlations between the aqueous phase components and monomers $[10,11]$, poly(MA-co-D(M)A) dispersions were synthesized. Their main

Table 1

The characteristics of the dispersions (the emulsifier content was 6 wt.\% with respect to the total monomer weight)

\begin{tabular}{|c|c|c|c|c|c|c|}
\hline 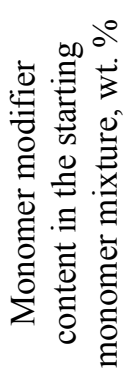 & 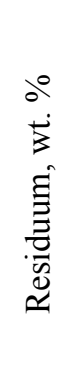 & 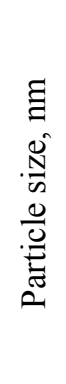 & 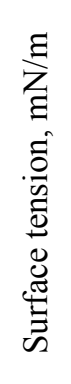 & 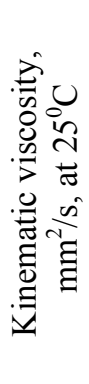 & 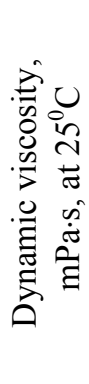 & 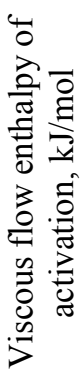 \\
\hline \multicolumn{7}{|c|}{ poly(MA) } \\
\hline- & 39.5 & 133 & 38.1 & 7.11 & 7.25 & 12.1 \\
\hline \multicolumn{7}{|c|}{ poly(MA-co-DA) dispersion } \\
\hline 5.0 & 39.5 & 121 & 38.4 & 7.98 & 8.14 & 12.3 \\
\hline 10.0 & 39.3 & 123 & 39.1 & 10.4 & 10.6 & 15.7 \\
\hline 15.0 & 39.1 & 119 & 40.6 & 14.3 & 14.6 & 12.2 \\
\hline 20.0 & 39.8 & 120 & 40.3 & 13.7 & 14.0 & 14.0 \\
\hline 25.0 & 38.8 & 121 & 40.2 & 13.4 & 13.7 & 15.7 \\
\hline \multicolumn{7}{|c|}{ poly(MA-co-DMA) dispersion } \\
\hline 5.0 & 38.6 & 119 & 40.3 & 8.28 & 8.45 & 13.9 \\
\hline 10.0 & 39.9 & 120 & 41.2 & 13.6 & 13.9 & 13.9 \\
\hline 15.0 & 39.9 & 117 & 41.8 & 19.5 & 19.9 & 12.2 \\
\hline 20.0 & 38.9 & 119 & 41.1 & 15.3 & 15.6 & 13.9 \\
\hline 25.0 & 39.0 & 116 & 40.8 & 13.7 & 14.0 & 13.9 \\
\hline
\end{tabular}


characteristics can be seen in Table 1 .

The residua of all synthesized dispersions are close to each other. However, the viscosity varies non-monotonously which indicates influencing the copolymer composition upon the type of the interaction between the particles and the aqueous phase (Table 1). An increase in the long-chain unit content slackens off the structure formed by ester groups, loosens the particles, which favors increasing hydrate shells around the ester groups, and increases the viscosity up to $\mathrm{D}(\mathrm{M}) \mathrm{A}$ content of $15 \mathrm{wt} . \%$. At the higher content of the long-chain monomers, which form the main structure of the macromolecule, a packing happens because of the dispersion interaction between long alcohol substituents that decreases hydrate shells around the ester groups. However, the complex structure of the relationship between the viscosity and copolymer composition is due to significant conformational alterations in macromolecules, which influence the hydrodynamic

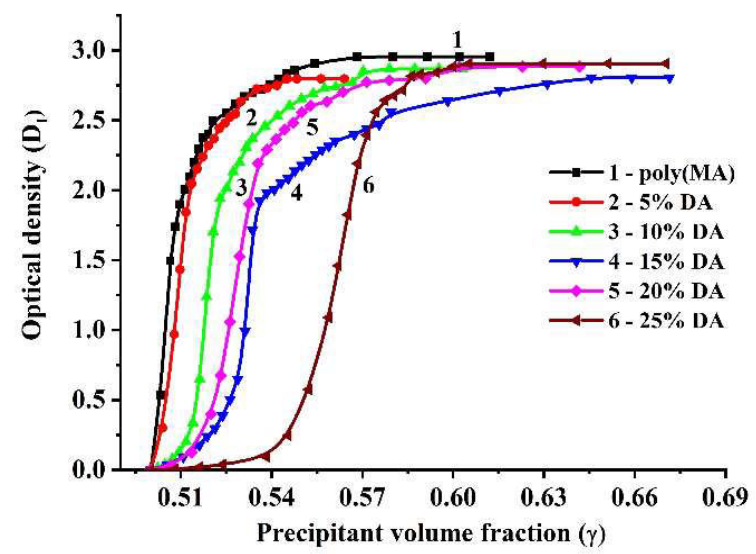

sizes of the particles of the dispersion.

Different relationship between the surface tension and copolymer composition is a consequence of two-factor impact: a decrease in the particle sizes which increases the emulsifier absorption due to enlarging an interphase boundary area, and an actual alteration in the absorption ability of an interphase boundary.

The molecular weight distribution (MWD) of the emulsion copolymers was studied by the turbidimetric titration of copolymer solutions in the system containing acetone (as a solvent) and water (as a precipitant). The slope of the integral and differential curves of turbidimetric titration is determined by different interactions between macromolecules and a solvent, which, in turn, depend upon a (co)polymer composition (Figs. 2 and 3 ).

This indicates different solubility and, consequently, different rate of the (co)polymer

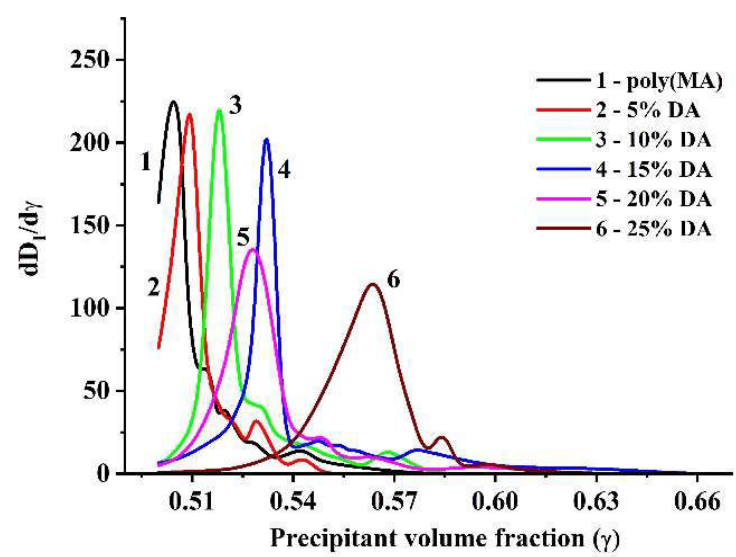

ab

Fig. 2. Data on turbidimetric titration of poly(MA-co-DA) solutions by water at a different DA concentration in the monomer mixture (wt.\%): (a) integral curves and (b) differential curves

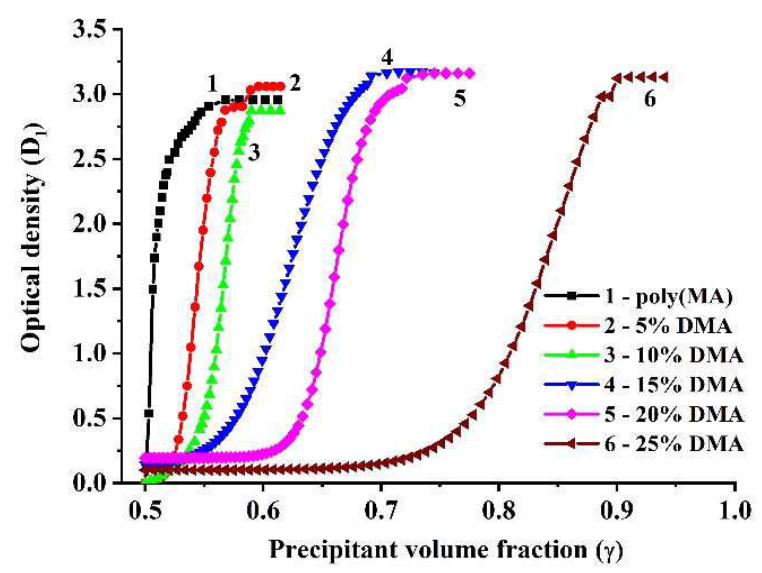

a

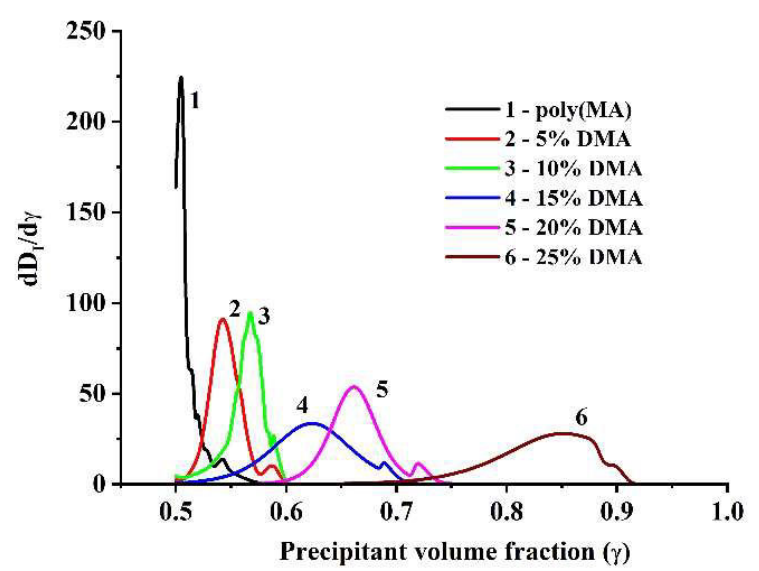

b

Fig. 3. Data on turbidimetric titration of poly(MA-co-DMA) solutions by water at different DMA concentrations in the monomer mixture (wt.\%): (a) integral curves and (b) differential curves 
precipitation. The bends in the curves are due to the appearance of the fraction with another composition.

The differential curves of turbidimetric titration show a clearly defined bimodality resulted from the presence of two fractions with different molecular weights. In the poly(MA) dispersion, this phenomenon is related to the presence of the fraction of those synthesized in poly(MA) (the main maximum) and in the aqueous phase (the series of the small maxima). In the differential curves of turbidimetric titration of the copolymers, the displacement of the maxima leads to an increase in the quantity of the precipitant. As a rule, this is due to a decrease in the molecular weight of (co)polymers. The poly-modality (positive tailing the differential titration for poly(MA-co-DA) (Fig. 2,b)) is associated with the formation of the copolymer fraction via the homogeneous nucleation mechanism in the aqueous phase. The MWD of the main fraction broadens with an increase in the DA content (Fig. 2).

According to the turbidimetric titration data, a similar effect on the MWD is observed in poly(MAco-DMA) (Fig. 3). However, the content of the main fraction in these copolymers has a wider MWD than that in poly(MA-co-DA).

The use of the (meth)acrylate dispersion to glue and form film materials is directly is related to the shaping of a film [12]. Therefore, the properties of dispersion films should investigated on the light of their practical application. We investigated water absorption, mechanical strength and specific elongation at rupture to analyze the effects of $\mathrm{D}(\mathrm{M}) \mathrm{A}$ on the properties of the films that are obtained by copolymerization with MA.

Water absorption varies disproportionately with an increase in the D(M)A content (Fig. 4). The curves describing the relative water absorption of

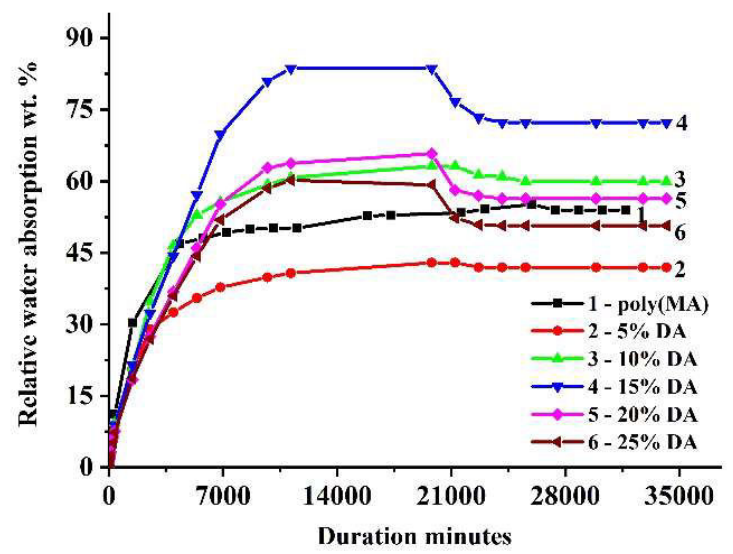

a

Fig. 4. Relative water absorption of the (co)polymer films versus duration at a different $\mathrm{D}(\mathrm{M}) \mathrm{A}$ concentration in the monomer mixture (wt.\%): (a) poly(MA-co-DA) film and (b) poly(MA-co-DMA) film the (co)polymer films show the sections of a rapid absorption, slow absorption, equilibrium and desorption of water-soluble components (Fig. 4). The diffusion coefficients were calculated based on the first section; these data showed a decrease in the rate of water absorption by the copolymer films as compared with the poly(MA) one (Table 2). The water absorption of the poly(MA-co-DMA) films is less than that of the poly(MA-co-DA) ones, which is caused by the influence of a methyl substituent in an $\alpha$-position on the polymer structure. Despite significant hydrophobic activity of the monomer modifier, the water absorption of the films disproportionately depends upon their content. This indicates the effects of various factors on this process. In the investigated time interval (reaching equilibrium or close to this state), the desorption of water-soluble components from the poly(MA-co-D(M)A) films is still in progress (Fig. 4).

The statistical estimate of the data on the tensile strength test and specific elongation during rupture was performed by using the Student distribution with a degree of reliability of 0.95 . The relative deviation of the tensile strength and specific elongation of the films were in the range of 4 to $25 \%$, though an increase in the content of monomer modifier facilitated a decrease in the relative error. The tensile strength of the poly(MA) and poly(MA-co-D(M)A) films decreases with increasing the amount of the long-chain monomers (Fig. 5,a), which indicates their plasticizing action. It should be noted that the tensile strength of the poly(MA-co-DA) films is less than that of the poly(MA-co-DMA) ones (Fig. 5,a); these results exactly coincide with the well-known facts concerning the influence of a methyl substituent in an $\alpha$-position on the properties of polymers [13]. Despite well-known regularities concerning the

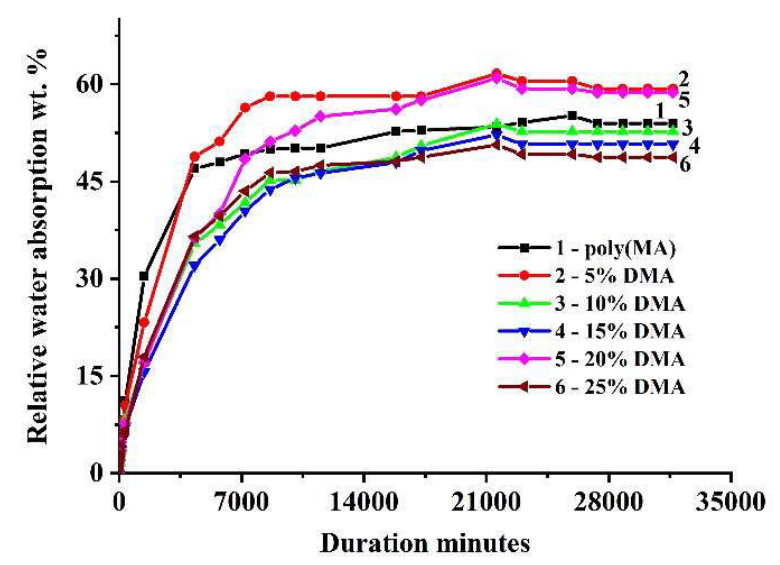

b 

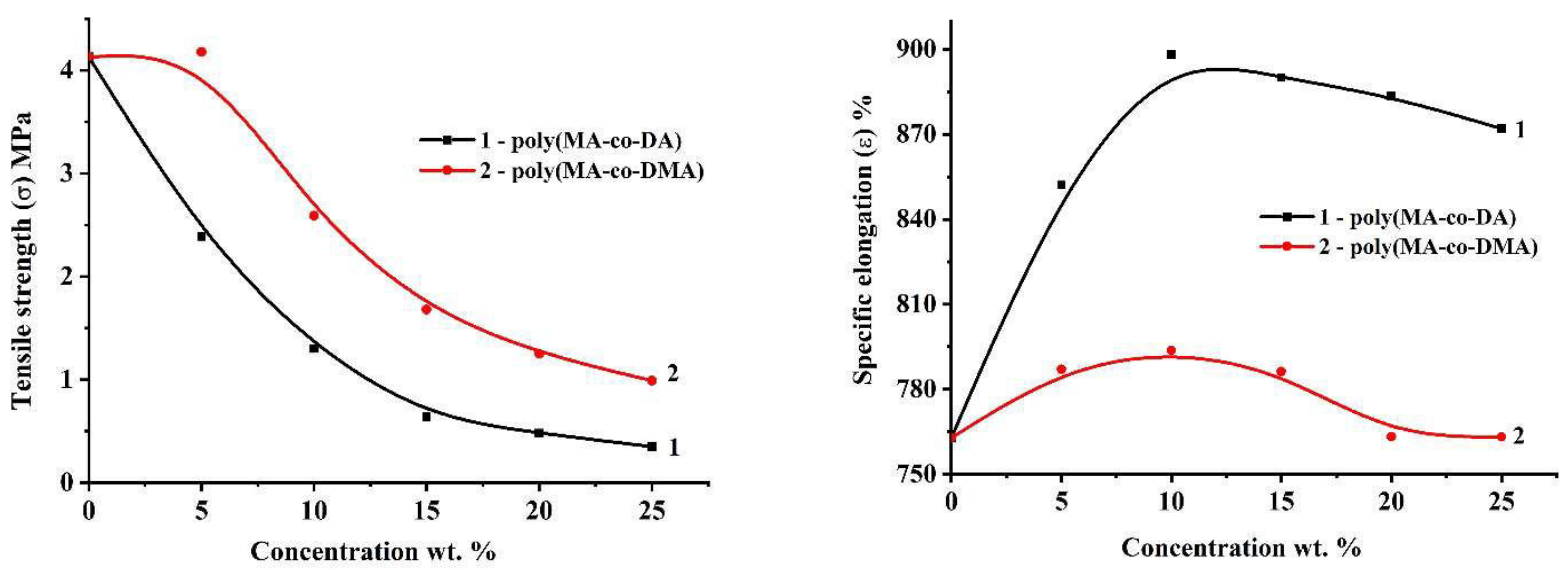

ab

Fig. 5. Physical-mechanical properties of poly(MA-co-DA) and poly(MA-co-DMA) films at different D(M)A concentration in the monomer mixture: (a) tensile strength and (b) specific elongation

Table 2 the presence of a methylene group. The long

The diffusion coefficients of water into the film

\begin{tabular}{|c|c|c|}
\hline $\begin{array}{c}\text { Monomer modifier } \\
\text { content in the film, } \\
\text { wt. } \%\end{array}$ & $\begin{array}{l}\text { Duration, } \\
\text { hours }\end{array}$ & $\begin{array}{l}\text { Diffusion coefficients } \\
\text { of water into the film, } \\
\mathrm{m}^{2} / \mathrm{s}\end{array}$ \\
\hline \multicolumn{3}{|c|}{ poly(MA) } \\
\hline- & 6 & $9.59 \cdot 10^{-11}$ \\
\hline \multicolumn{3}{|c|}{ poly(MA-co-DA) dispersion film } \\
\hline 5.0 & \multirow[t]{5}{*}{ 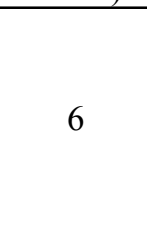 } & $9.83 \cdot 10^{-11}$ \\
\hline 10.0 & & $7.32 \cdot 10^{-11}$ \\
\hline 15.0 & & $1.27 \cdot 10^{-10}$ \\
\hline 20.0 & & $4.53 \cdot 10^{-11}$ \\
\hline 25.0 & & $4.00 \cdot 10^{-11}$ \\
\hline \multicolumn{3}{|c|}{ poly(MA-co-DMA) dispersion film } \\
\hline 5.0 & \multirow{5}{*}{24} & $8.64 \cdot 10^{-10}$ \\
\hline 10.0 & & $3.44 \cdot 10^{-11}$ \\
\hline 15.0 & & $5.80 \cdot 10^{-11}$ \\
\hline 20.0 & & $2.97 \cdot 10^{-11}$ \\
\hline 25.0 & & $3.23 \cdot 10^{-11}$ \\
\hline
\end{tabular}

changes of the film specific elongation when adding a modifier [14], an increase in the monomer modifier content leads to an increase in the film specific elongation (Fig. 5,b).

To confirm the composition of the (co)polymers, IR spectroscopy of the corresponding films was used (Fig. 6). Absorptions, which are attributed to ester and methylene groups, are present in the dispersion (co)polymer films. A very strong absorption at $1736 \mathrm{~cm}^{-1}$ is assigned to $\mathrm{C}=\mathrm{O}$ stretch. Valency vibrations $(\mathrm{C}-\mathrm{O})$ of esters, in fact, consists of two different components, which interact mutually: $(\mathrm{C}-\mathrm{C}(=\mathrm{O})-\mathrm{O})$ and $(\mathrm{O}-\mathrm{C}-\mathrm{C})$. The mentioned absorptions are observed at 1337 and $1168 \mathrm{~cm}^{-1}$. The absorptions at 2952, 2648 and $1442 \mathrm{~cm}^{-1}$ suggest hydrocarbon fragment of decyl (meth)acrylate is indicated by absorptions at 2928 and $2856 \mathrm{~cm}^{-1}$; absorption at $1376 \mathrm{~cm}^{-1}$ reveals the presence of a methyl group.

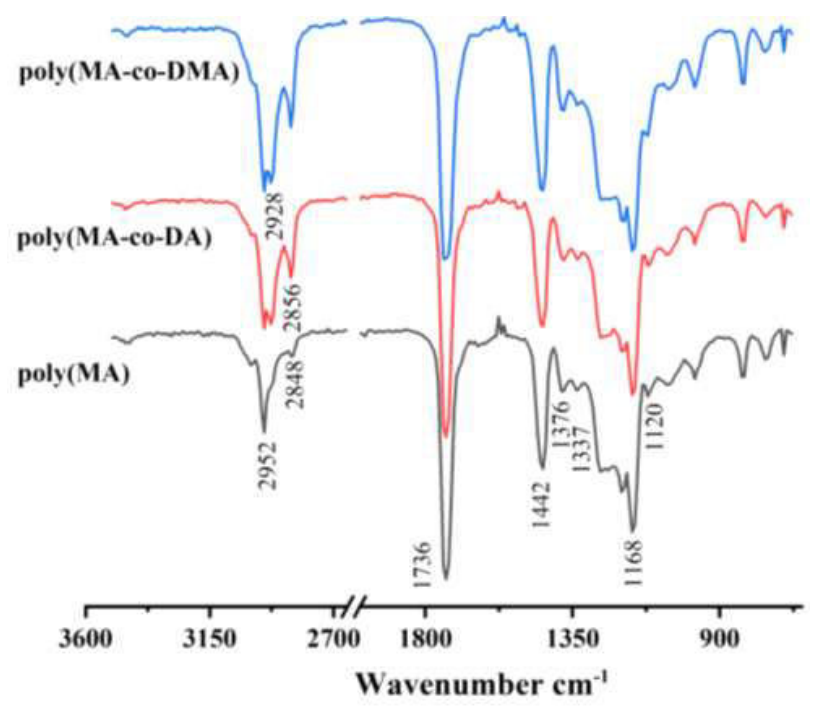

Fig. 6. IR spectra of the (co)polymer films

\section{Conclusions}

The emulsion homopolymerization of methyl acrylate and copolymerization of methyl acrylate with decyl acrylate and decyl methacrylate was studied. According to our findings, a significant deceleration of the copolymerization rate is caused by structural transformations in a micelle and by prevention of initiating particles from their deep penetrating into the PMP, which contains long-chain monomers.

The structural transformations of 
macromolecules in the copolymer dispersion of methyl acrylate with decyl acrylate and decyl methacrylate are due to the change of the particle size and absorption capacities of their surface. This, in turn, influences non-monotonous dependences of the viscosity and surface tension of the dispersions as well as the physical-mechanical properties of the dispersion films on the content of decyl (meth)acrylate.

\section{REFERENCES}

1. Frustrated crystallisation and hierarchical self-assembly behaviour of comb-like polymers / Shi H., Zhao Y., Dong X., Zhou Y., Wang D. // Chem. Soc. Rev. - 2013. - Vol.42. No. 5. - P.2075-2099.

2. Interface radical reactions of functional polyperoxides for fabrication of three-dimensional polymeric structures / Samaryk V., Voronov A., Tarnavchyk I., Varvarenko S., Nosova N., Kohut A., Voronov S. // Radical Polymerization: New Developments. - Nova Science Publishers Inc. - 2012. P.1-57.

3. Plate N.A., Shibaev V.P. Comb-shaped polymers and liquid crystals. - New York: Springer, 1987. - 415 p.

4. Мисак Й.С., Коваленко Т.П., Сердюк В.О. Одержання легованої індустріальної оливи для устаткування електростанцій // Энерготехнологии и ресурсосбережение. - 2014. - № 4. - C.21-27.

5. Obtaining of polymethacrylate additives and studying of operational properties of an alloyed industrial oil / Mysak Y., Kovalenko T., Serdiuk V., Kravets T., Martynyak-Andrushko M. // East.-Eur. J. Enterprise Technol. - 2016. - Vol.3. No. 6(81). - P.9-16.

6. Atta A.M., Al-Shafy H.I., Ismail E.A. Influence of ethylene acrylic alkyl ester copolymer wax dispersants on the rheological behavior of Egyptian crude oil // J. Dispersion Sci. Technol. 2011. - Vol.32. - No. 9. - P.1296-1305.

7. Волошинець В.А., Ван-Чин-Сян Ю.Я., Ганишнюк Т.А. Структурні перетворення дисперсій кополімерів бутилакрилату-метилакрилату-метакрилової кислоти // Полімерний журнал. - 2006. - № 4. - С. 28-335.

8. Коваленко Т.П., Красінська Н.В., Волошинець В.А. Розрахунок кінетичних параметрів естерифікації деканолу1 акриловою кислотою // Вісник Нац. ун-ту «Львівська політехніка». Сер. Хімія технологія речовин та їх застосування. - 2006. - № 553. - C.65-69.

9. Molecular mobility in polymers with long-chain side groups / Borisova T.I., Burshtein L.L., Shevelev V.A., Shibayev V.P., Plate N.A. // Polym. Sci. U.S.S.R. - 1971. - Vol.13. - No. 10. - P.2619-2630.
10. Волошинеи В.А., Собечко И.Б., Кочубей В.В. Синтез акриловых дисперсий метилакрилата с малеиновой кислотой и исследование термостабильности синтезированных полимеров // Пластические массы. - 2005. - № 10. - С.2931.

11. Волошинець В.А., Маршалок О.І. Синтез та дослідження кополімерів метилакрилату з метилметакрилатом // Вопросы химии и хим. технологии. - 2006. - № 5. - С.134137.

12. Волошинець В.А., Павловська О.Ю. Синтез, властивості дисперсій та плівок поліметилакрилату // Вісник Нац. ун-ту «Львівська політехніка». Сер. Хімія, технологія речовин та їх застосування. - 2005. - № 536. - С.50-55.

13. Николаев А.Ф. Синтетические полимеры и пластические массы на их основе. - М.-Л.: Химия, 1964. -784 с.

14. О структуре сшитых полимеров с гидрофильными функциональными группами / Елисеева В.И., Пинская И.С., Чалых А.Е. и др. // Высокомолекулярные соединения. 1973. - T.14(A). - № 9. - C.1931-1935.

Received 18.05.2019

\section{ЕМУЛЬСІЙНІ (КО)ПОЛІМЕРИ МЕТИЛАКРИЛАТУ 3 ДЕЦИЛ(МЕТ)АКРИЛАТАМИ: СИНТЕЗ І ВЛАСТИВОСТІ}

\section{Т.П. Коваленко, В.О. Сердюк, В.Б. Вострес, Г.Ф. Матіко}

У роботі вперше здійснено кінетичні дослідження емульсійної (ко)полімеризації децилмет- та децилакрилату з метилакрилатом та одержсано кополімери на їх основі. Встановлено, що децил(мет) акрилати не гомополімеризуються в емульсії незалежно від природи емульгатора, розчинності, будови ініціатора та зменшують швидкість кополімеризації з метилакрилатом. Сповільнення кополімеризації в присутності довголаниюгових мономерів пов'язане з більи низькою активністю децил(мет) акрилату в кополімеризації у порівнянні з метилакрилатом. Досліджено колоїдно-хімічні та фізико-хімічні властивості синтезованих дисперсій. Встановлено, що положення максимуму у залежності в 'язкості та поверхневого натягу від складу кополімера співпадає з найменшими розмірами частинок дисперсій $i$, відповідно, часткова зміна в язкості та поверхневого натягу дисперсій зумовлена зміною розмірів частинок $i$, відповідно, зміною площі міжфазної поверхні. Вивчено молекулярно-масовий розподіл емульсійних кополімерів методом турбідиметричного титрування. Досліджено водопоглинання, міиність та відносне видовження під час розриву (ко)полімерних плівок. Розраховано коефічієнти дифузії за даними першої ділянки кривих водопоглинання, які свідчать про зменшення швидкості поглинання води плівками кополімерів порівняно $з$ плівками поліметилакрилату. Показано, що міцність плівок на розрив кополімерів метилакрилат-децилакрилат менша за міиність плівок кополімерів метилакрилат-децилметакрилат, що збігається з загальновідомими фактами впливу метильного замісника в $\alpha$-положенні на властивості полімерів. Показано, що внесення гідрофобних комономерів - децилмет- $i$ децилакрилату в структуру макромолекул з метилакрилатом суттєво впливає на властивості дисперсій та плівок одержаних з них, що пов'язано зі значними структурними перетвореннями макромолекул у дисперсіях і плівках.

Ключові слова: кінетичні дослідження, емульсійна (ко)полімеризація, децил(мет)акрилат, метилакрилат, колоїдно-хімічні та фізико-механічні властивості. 


\section{EMULSION COPOLYMERS OF METHYL ACRYLATE AND DECYL (METH)ACRYLATE: SYNTHESIS AND PROPERTIES}

\section{T.P. Kovalenko *, V.O. Serdiuk, V.B. Vostres, H.F. Matiko \\ Lviv Polytechnic National University, Lviv, Ukraine \\ *e-mail: kovalenkotaniy@gmail.com}

This paper reports a kinetic investigation into the emulsion (co)polymerization of decyl meth-and decyl acrylate with methyl acrylate for the first time. The obtained results are used to prepare copolymers based on the products of the emulsion (co)polymerization. It is determined that decyl methacrylate does not homopolymerize with the formation of emulsions regardless of the nature of an emulsifier, its solubility and initiator structure. Moreover, they reduce the rate of copolymerization with methyl acrylate. The deceleration of the copolymerization in the presence of long-chain monomers is related to the a low activity of decyl (meth)acrylate as compared with methyl acrylate. The colloid-chemical and physicochemical properties of the synthesized dispersions are investigated. The position of the maximum of the dependences of viscosity and surface tension on the polymer composition coincides with the smallest particle sizes of the dispersion; hence, the alterations in the viscosity and surface tension of the dispersion are associated with the variations in particle sizes, which results in the changes in the interface surface area. The molecular weight distribution of emulsion copolymers is studied by a turbidimetric titration technique. The absorption of water, the strength and specific elongation of the (co)polymer films are determined by tension testing. Diffusion coefficients are calculated according to the first section of the water absorption curve; the obtained values show the deceleration of the rate of the water absorption by the copolymer film as compared with the polymethyl-acrylate films. The tensile strength of the poly(methyl acrylate-co-decyl acrylate) films is less than that of the poly(methyl acrylate-co-decyl methacrylate) ones, which corresponds with the well-known facts concerning the influence of a methyl substituent in an $\alpha$-position on the polymer properties. The addition of hydrophobic co-monomers, decyl meth-and decyl acrylate, to the structure of macromolecules with methyl acrylate strongly affects the properties of the dispersion and derived films, which is connected with the significant structural transformations of macromolecules in the dispersions and films.

Keywords: kinetic investigation; emulsion (co)polymerization; decyl (meth)acrylate; methyl acrylate; colloidchemical and physicochemical properties.

\section{REFERENCES}

1. Shi H., Zhao Y., Dong X., Zhou Y., Wang D. Frustrated crystallisation and hierarchical self-assembly behaviour of comblike polymers. Chemical Society Reviews, 2013, vol. 42, pp. 20752099.

2. Samaryk V., Voronov A., Tarnavchyk I., Varvarenko S., Nosova N., Kohut A., Voronov S. Interface radical reactions of functional polyperoxides for fabrication of three-dimensional polymeric structures. In: Paulauskas I.O., Urbonas L.A. (eds.). Radical Polymerization: New Developments. Nova Science Publishers Inc., 2012, pp. 1-57.

3. Plate N.A., Shibaev V.P. Comb-shaped polymers and liquid crystals. Springer, 1987. $415 \mathrm{p}$.

4. Mysak Y.S., Kovalenko T.P., Serdiuk V.O. Oderzhann'ya legovanoyi industrialnoyi olyvy dl'ya ustatkuvann'ya elektrostantsii [Preparation of doped industrial oil for equipment of power plants]. Energotekhnologii i Resursosberezhenie, 2014, no. 4, pp. 21-27. (in Ukrainian).
5. Mysak Y., Kovalenko T., Serdiuk V., Kravets T., Martynyak-Andrushko M. Obtaining of polymethacrylate additives and studying of operational properties of an alloyed industrial oil. Eastern-European Journal of Enterprise Technologies, 2016, vol. 3, no. 6(81), pp. 9-16.

6. Atta A.M., Al-Shafy H.I., Ismail E.A. Influence of ethylene acrylic alkyl ester copolymer wax dispersants on the rheological behavior of Egyptian crude oil. Journal of Dispersion Science and Technology, 2011, vol. 32, pp. 1296-1305.

7. Voloshynets V.A., Van-Chyn-Sian Yu.Ya., Hanyshniuk T.A. Strukturni peretvorennia dyspersii kopolimeriv butylakrylatumetylakrylatu-metakrylovoi kysloty [Structural transformations of the dispersion of copolymers of butacrylate, methacrylate and methacrylic acid]. Polimernyi Zhurnal, 2006, no. 4, pp. 28-335. (in Ukrainian).

8. Kovalenko T.P., Krasinska N.V., Voloshynets V.A. Rozrakhunok kinetychnykh parametriv esteryfikatsii dekanolu-1 akrylovoiu kyslotoiu [Calculation of the kinetic parameters of esterification of decanol by acrylic acid]. Visnyk Natsionalnogo Universytetu «Lvivska Politekhnika». Khimiya, Tekhnologiya Rechovyn ta Yikh Zastosuvannya, 2006, no. 553, pp. 65-69. (in Ukrainian).

9. Borisova T.I., Burshtein L.L., Shevelev V.A., Shibayev V.P., Plate N.A. Molecular mobility in polymers with long-chain side groups. Polymer Science U.S.S.R, 1971, vol. 13, no. 10, pp. 26192630.

10. Voloshinetc V.A., Sobechko I.B., Kochubei V.V. Sintez akrilovykh dispersii metilakrilata s maleinovoi kislotoi i issledovanie termostabil'nosti sintezirovannykh polimerov [Synthesis of acrylic dispersions with maleic acid and investigation of the thermal stability of synthesized polymers]. Plasticheskie Massy, 2005, no. 10, pp. 29-31. (in Russian).

11. Voloshynets V.A., Marshalok O.I. Syntez ta doslidzhennya kopolimeriv metylakrylatu z metylmetakrylatom [Synthesis and investigation of co-polymers of methacrylate with methyl-methacrylate]. Voprosy Khimii i Khimicheskoi Tekhnologii, 2006, no. 5, pp. 134-137. (in Ukrainian).

12. Voloshynets V.A., Pavlovska O.Yu. Syntez, vlastyvosti dyspersii ta plivok polimetylakrylatu [Synthesis and properties of the dispersions and films of polymethylmethacrylate]. Visnyk Natsionalnogo Universytetu «Lvivska Politekhnika». Khimiya, Tekhnologiya Rechovyn ta Yikh Zastosuvannia, 2005, no 536, pp. 50-55. (in Ukrainian).

13. Nikolaev A.F., Sinteticheskie polimery i plasticheskie massy na ikh osnove [Synthetic polymers and plastic masses based on them]. Khimiya, Moscow-Leningrad, 1964. 784 p. (in Russian).

14. Eliseeva V.I., Pinskaia I.S., Chalykh A.E. O strukture sshytykh polimerov s gidrofilnymi funktsionalnymi gruppami [On the structure of the cross-linked polymers with hydrophilic functional groups]. Vysokomolekuliarnye Soedineniya, 1973, vol. 14(A), no. 9, pp. 1931-1935. (in Russian). 